\title{
Chapter 14 \\ Global Developments: Policy Support for Linking Biodiversity, Health and Climate Change
}

\author{
Horst Korn, Jutta Stadler, and Aletta Bonn
}

\begin{abstract}
This chapter highlights key policy processes at the international level dealing with the alignment of policies for the biodiversity-climate-health nexus. Recent developments by UN Conventions and major international organisations, such as the Convention on Biological Diversity, the Ramsar Convention and the United Nations Framework Convention on Climate Change (UNFCCC), together with the World Health Organization (WHO) and the Intergovernmental SciencePolicy Platform on Biodiversity and Ecosystem Services (IPBES), are discussed. Special attention is given to newly emerging integrative global policy processes and partnerships between the Convention on Biological Diversity and the WHO, also in the framework of the Agenda 2030 for Sustainable Development and avenues to translate them into local policy through the global partnership ICLEI - Local Governments for Sustainability. Conclusions are drawn to foster the joint implementation of policy goals.
\end{abstract}

Keywords Biodiversity-climate-health nexus $\cdot$ Science-policy interface $\cdot$ UN conventions $\cdot$ CBD partnership $\cdot$ IPBES $\cdot$ SDG goals

\section{Highlights}

- Policy agendas of health promotion, climate change adaptation and biodiversity conservation are starting to become aligned.

\section{H. Korn $(\bowtie) \cdot$ J. Stadler}

Federal Agency for Nature Conservation (BfN), Isle of Vilm, Putbus, Germany e-mail: horst.korn@bfn.de; jutta.stadler@bfn.de
A. Bonn
Department of Ecosystem Services, Helmholtz Centre for Environmental Research - UFZ,
Leipzig, Germany
German Centre for Integrative Biodiversity Research (iDiv) Halle-Jena-Leipzig,
Leipzig, Germany
Institute of Biodiversity, Friedrich Schiller University Jena, Jena, Germany
e-mail: aletta.bonn@ufz.de 
- Alignment of indicators, joint metrics and reporting for health, climate change adaptation and biodiversity is needed to work effectively across different sectors.

- Joint collaborative working and governance is needed to put policy agendas into practice and foster implementation across sectors.

\subsection{Introduction}

Biodiversity forms the foundation of life on Earth and human health, as it underpins the functioning of ecosystems and associated ecosystem services (Cardinale et al. 2012). We depend on the contributions from nature to people (Díaz et al. 2018) for providing our food and fresh water, regulating climate, preventing floods and disease, as well as providing recreational benefits and aesthetic and spiritual enrichment (see also Irvine et al. Chap. 10, this volume). Biodiversity contributes to both traditional and modern medicines and supports local livelihoods and economic development (Romanelli et al. 2015). Because of these fundamental linkages between biodiversity and human health, it is surprising that this important crosscutting issue made it -only in the last few years - prominently onto the agendas of important international conventions and organisations such as the Convention on Biological Diversity (CBD), the Ramsar Convention on Wetlands and the World Health Organization (WHO). Given the fact that climate change increasingly has direct and indirect effects on both biodiversity and human health, it is even more important to stress the links between the topics in order to foster nature-based solutions for promoting health and adapting to climate change.

This chapter highlights some key policy processes to tackle the relationships between (1) biodiversity and climate change, (2) biodiversity and health, (3) climate change and health and (4) the biodiversity-climate-health nexus on the international level. The field is developing fast, and this chapter represents the status as of August 2018. The connection between biodiversity and health - sometimes also in relation to climate change - is also emerging in many practical regional and local initiatives, coming from both a nature conservation angle and a medical angle. (For an overview about European Nature and Health network initiatives see Keune et al. Chap. 15 , this volume.)

\subsection{Biodiversity and Climate Change}

Much work has been done on the direct effects of climate change on biodiversity (e.g. changes in phenology and in species' distribution, composition and interactions; see Bellard et al. 2012; Parmesan 2006; Thomas et al. 2004) as well as indirect effects of these changes on human health (Pecl et al. 2017). But vice versa, biodiversity also affects the climate system and can also ameliorate climate change 


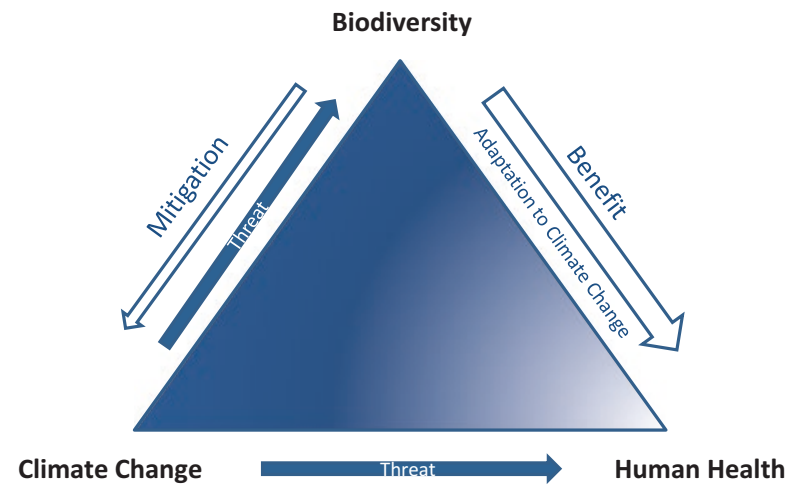

Fig. 14.1 Relationship between biodiversity, climate change and health. White arrows indicate a positive impact; dark arrows indicate a negative impact. The thickness of the lines corresponds to the strength of the impact

effects through nature-based mitigation (e.g. through carbon sequestration and carbon storage in vegetation or soils; see e.g. IPCC 2014) and adaptation measures (Lo 2016) (see Fig. 14.1). The latter - for example, reducing the urban heat island effect and disaster risk - have strong implications for human health and well-being. This was taken up and elaborated on by major international policy processes such as the Ramsar Convention on Wetlands in its resolutions (e.g. see Resolution XII.13: Wetlands and disaster risk reduction (Ramsar 2015)) and related activities reflected in the themes of the World Wetlands Days 2017 "Wetlands for Disaster Risk Reduction", and 2018 "Wetlands for a sustainable urban future". Ecosystem-based approaches to adapting to climate change and reducing disaster risk have also been an important topic in the processes of the CBD (Lo 2016).

\subsection{Biodiversity and Health}

The emergence of the ecosystem service concept led to the Millennium Ecosystem Assessment (MA 2005) with its synthesis report on health (Corvalan et al. 2005) followed by the Economics of Ecosystems and Biodiversity reports (TEEB 2010) and several national assessments (Schröter et al. 2016). These assessments mainly focused on economic benefits of nature and mention health benefits only little or less explicitly.

In the policy arena, the international treatment of the linkages of health and biodiversity began with the $\mathrm{COHAB}$ Initiative that was established in response to outputs of the First International "Conference on Health and Biodiversity - COHAB 2005", which took place in Galway, Ireland in August 2005 (see Box 14.1). The recommendations from that meeting addressed a number of key issues at the interface of biodiversity and human well-being, and raised issues of governance, equity 


\section{Box 14.1 Co-operation on Health and Biodiversity - COHAB Initiative}

The COHAB Initiative operates through Partnership arrangements with a growing network of organisations worldwide, representing government and multi-lateral agencies, academic institutes, NGOs, indigenous communities and the private sector. These organisations share a common interest - to enhance co-operation between the health and biodiversity sectors, working together for a healthy planet with healthy people. Major areas of focus include:

- Poverty reduction and livelihood security

- Food security, nutrition and dietary health

- Emerging diseases

- Natural products and medicinal resources

- Disaster prevention, relief and recovery

- Traditional knowledge

- Indigenous community health

- Social and spiritual well-being and mental health.

COHAB Initiative Partnership arrangements provide a framework within which organisations may collaborate to increase the effectiveness of their efforts in addressing the issues linking the conservation and sustainable use of biodiversity with health, well-being and livelihood security. Partners range from Intergovernmental organisations (mainly from the UN-System), to international non-governmental organisations and a variety of country-based organisations.

(http://www.cohabnet.org, accessed 25.05.2018)

and participation. These were the core issues around which the COHAB Initiative was then established (COHAB 2005), and which provided the basis for further development of the topic. The COHAB Initiative, which is less active now, had a strong influence to put the topic on the agenda of the CBD and stimulated the joint work programme of the CBD and the WHO, which are now the main global actors in this field (see sect. 14.5.2).

\subsection{Climate Change and Health}

The direct link between climate change and health issues is well developed (e.g. WHO 2016; Wolf et al. 2015; see also Lindley et al. Chap. 1, Hunter et al. Chap. 17, both this volume). Already in 2008 the World Health Assembly developed a global Work Plan to support member states in climate change and health protection that 
was updated in 2014 (WHO 2015). ${ }^{1}$ In 2015, the Lancet Commission on Health and Climate Change prominently recommended ten concise policy actions for the next 5 years on climate change adaptation to protect public health (Watts et al. 2015), which urged joint working across sectors and scaling up of investments to secure a climate-resilient public health system. Human health was also included as an important aspect in the European Environment Agency indicator report on climate change (Füssel et al. 2017). International policy commitments were documented in the Paris Agreement of the United Nations Framework Convention on Climate Change (UNFCCC), which recognised "the social, economic and environmental value of voluntary mitigation actions and their co-benefits for adaptation, health and sustainable development"(UN 2015a).

Unfortunately, the interlinkages between climate change, health and biodiversity only gained little attention within international climate policy, so far.

\subsection{Biodiversity-Climate-Health Nexus}

Despite the many activities in the individual fields of biodiversity conservation, climate change mitigation and adaptation as well as the improvement of human health, the benefits that intact ecosystems can provide to people's health in the face of climate change has only been recognised slowly during the last decade. There are many opportunities to bring the three topics of biodiversity, health and climate together in a constructive way and to tackle real issues. Biodiversity can help to prevent or minimise human-induced or natural disasters that are caused or accelerated by climate change.

For example:

1. Biodiversity can help human societies to adapt better to climate change induced heat waves in urban areas (see Lindley Chap. 1, this volume; overviews in Kabisch et al. 2017).

2. Biodiversity in the form of floodplain or mangrove ecosystems can help to protect human populations from the impact of severe floods partly caused by climate change (Temmerman et al. 2013).

3. Different species or varieties of plants and animals can help to adapt agricultural systems to climate change, so that they can provide sufficient nutrients and healthy diets (Lin 2011).

The emphasis of policy linkages was first on wetlands (see below) and naturebased solutions in urban areas (Kabisch et al. 2016, 2017; WHO Regional Office for Europe 2016), while the biodiversity-climate-health nexus has also been considered in much broader applications (see also Romanelli et al. 2015). In the following sec-

\footnotetext{
${ }^{1}$ For an overview of policy measures see http://www.who.int/globalchange/health_policy/en/ (accessed 8 August 2018).
} 
tions we provide some examples of international policy processes that take an integrative approach.

\subsubsection{RAMSAR-Convention}

In 2012, the Ramsar Convention published a Technical Report "Healthy wetlands, healthy people" (Horwitz et al. 2012) that extensively reviewed the relationship between biodiversity (here in the form of wetland ecosystems), climate change and human health. The evidence of ecosystem services of wetlands and their benefits to human health and livelihoods was considered to be well established. Wetlands can provide food and shelter, flood control and mitigation of climate change through carbon storage as well as modes of transport and sources of beneficial drugs. As such the maintenance of 'healthy wetlands', including people as part of wetlands, was therefore considered to be very important. Nevertheless, it was also stated that the current understanding of climate change-induced increases in health and disease risks in wetlands should be taken into account when co-managing wetlands and human health. Decision-making should seek to maintain the capacity of wetlands to adapt to climate change, as functioning mangroves or floodplains and other wetlands can provide important buffers to climate-induced extreme events and associated risks of human health problems (Horwitz and Finlayson 2011), including risks of vector-borne diseases (see Müller et al. Chap. 4, this volume).

A draft version of the Ramsar report was already issued as a background document for the Ramsar COP 10 (Ramsar 2008) and led to Ramsar Resolution X.23, which recognised that the changing climate is expected to continue to increase the risk to human health of matters associated with wetland ecosystems. Importantly, the resolution emphasised tackling health risks, but also considered principles of equity and prevention in public health measures through wetlands. Contracting parties were urged to ensure that decision-making on co-managing wetlands and human health issues takes into account current understanding of climate change-induced increases in health and disease risk. The resolution text reflected the suggestions from the expert report (see above).

In Resolution XI.12 on Wetlands and Health (Ramsar 2012), the Conference of Parties to the Ramsar Convention raised the concern that threats to wetlands like climate change can act as drivers for disease emergence and re-emergence beyond natural cycles. Nevertheless, this link between wetlands, health and climate change is not directly addressed in the operative paragraphs of the resolution.

Three years later, as one of the outcomes of Ramsar COP 12 the Conference of Parties identified in Resolution XII.13 (Ramsar 2015) the link between wetlands and disaster risk reduction, and stated that healthy and well-managed wetlands can reduce disaster risk. Since many risks are expected to increase with climate change, joint work between technical and nature-based solutions to disaster risk reduction will be needed to secure human health. 
Several resolutions of the Ramsar convention have led the way to link biodiversity with health issues and disaster risk reduction in a holistic way, also referring to climate change. This expertise now needs to support the aims of the 2030 Sustainable Development Goals (SDGs) and is an important contribution to the 2050-Vision of the CBD.

\subsubsection{World Health Organization and Convention on Biological Diversity Partnership}

Although health is already mentioned in the Preamble to the text of the Convention on Biological Diversity (CBD 1992) ${ }^{2}$ and was included in the CBD Aichi Target 14, in 2010 (CBD 2010), ${ }^{3}$ the first full CBD decision on biodiversity and human health, under the joint work programme with the World Health Organization, was only concluded at the 12th Conference of the Parties, held in November 2014 in Pyeongchang, South Korea (CBD 2014). "All human health ultimately depends on ecosystem services that are made possible by biodiversity and the products derived from them. While the inter-linkages between biodiversity, ecosystem services and human health are inherently complex, inter-disciplinary research is aiming to develop a more thorough understanding of these essential relationships". ${ }^{4}$

Important for preparation of the next COP was a joint report with the title "Connecting Global Priorities: Biodiversity and Human Health, a State of Knowledge Review" that was published in 2015 by the Secretariat of the Convention of Biodiversity together with the World Health Organization and numerous partners (Romanelli et al. 2015). It covers a wide range of topics concerning both terrestrial and aquatic ecosystems. A focus lies on the contribution of biodiversity to physical health through provision of food and nutrition as well as pharmaceuticals and traditional medicines. Further, the report deals with regulating services of water and air quality as well as the contribution of biodiversity to mental and cultural well-being. Health aspects include consideration of the microbial diversity as well as noncommunicable and infectious diseases. Strategically, this report already considers links to global adaptation to climate change and associated disaster risk-reduction considerations, necessary tools, metrics and research avenues, and ultimately how

\footnotetext{
${ }^{2} \mathrm{CBD}$, Preamble: "Aware that conservation and sustainable use of biological diversity is of critical importance for meeting the food, health and other needs of the growing world population, for which purpose access to and sharing of both genetic resources and technologies are essential,..." (see: https://www.cbd.int/convention/articles/default.shtml? $\mathrm{a}=$ cbd-00, accessed 8 August 2018).

${ }^{3}$ Aichi target 14: "By 2020, ecosystems that provide essential services, including services related to water, and contribute to health, livelihoods and well-being, are restored and safeguarded, taking into account the needs of women, indigenous and local communities, and the poor and vulnerable." (see: https://www.cbd.int/decision/cop/default.shtml?id=12268, accessed 8 August 2018).

${ }^{4}$ For an overview of COP decisions and SBSTTA recommendations related to health see https:// www.cbd.int/health/ accessed 8 August 2018).
} 
strategies for health and biodiversity can contribute to achieving the SDGs and thereby align conservation, health and climate goals in a comprehensive way.

This report formed the basis for the further development of the topic on Biodiversity and Human Health at the CBD-COP13 in Mexico (CBD 2016b). In this decision, parties, other governments and relevant organisations are invited to carry out a wide range of comprehensive, integrative and far-reaching activities based on identified interlinkages at various levels and between different sectors. The Annex contains a comprehensive list of health-biodiversity linkages, which provides a good source of information when dealing with other sectors.

Following the COP13-Decision the field progressed rapidly, and already at the following meeting of the CBD-SBSTTA (Subsidiary Body on Scientific, Technical and Technological Advice) the subject on the scientific and technical side (CBD 2017) was further developed. SBSTTA draws on information inter alia from new reports issued by the Regional Office for Europe of the World Health Organization on the evidence of urban green spaces for health in 2016 (WHO Regional Office for Europe 2016), which was followed swiftly by a review of the impact of actual interventions in urban areas and their effectiveness (WHO Regional Office for Europe 2017). The SBSTTA-Recommendation stresses again the collaboration of different international organisations, and the national integration of biodiversity and health aspects into different sectors as vitally important, so that a holistic treatment of the topic is possible. The topic will therefore remain high on the international agenda.

A memorandum of understanding was signed between the CBD and the WHO in 2015, which provides a solid base for cooperation (WHO and CBD 2015), and also through an interagency liaison group on biodiversity and health that was established in 2017. ${ }^{5}$ During its first meeting, important areas of further work were identified, such as the need for indicators for biodiversity and health and the development of simple messages around topics like: (1) ecosystem degradation, (2) diversity of diets/nutrition, (3) urban green spaces and (4) prevention. Climate change is treated here as a cross-cutting issue (CBD and WHO 2017).

In 2017, the WHO also co-sponsored the international conference "Biodiversity and Health in the face of climate change - Challenges, Opportunities and Evidence Gaps" (Marselle et al. 2018), which was organised by the German Federal Agency for Nature Conservation (BfN) and the European Network of Heads of Nature Conservation Agencies (ENCA), and which led to formal ENCA recommendations that are further elaborated on in the concluding chapter of this volume (Marselle et al. Chap. 20).

The CBD-COP-Decision XIII/3 to enhance implementation of the Aichi targets and to mainstream and integrate biodiversity within and across sectors (CBD 2016a) identified health as one of four key mainstreaming sectors for the 2050 Vision of Biodiversity, which should be taken up in post-2020 consideration of the CBD and is already an agenda topic of the 14th Conference of the Parties to take place in Egypt in November 2018.

\footnotetext{
${ }^{5}$ See: https://www.cbd.int/health/ilg-health/default.shtml
} 
So far, the WHO European Health 2020 Framework mainly deals with the connection of health and the environment in relation to pollution and, for example, safe outdoor play for children (WHO 2017). However, the further collaboration between the CBD and the WHO may fuel the recognition of the importance of biodiversity for human health, in particular in the face of climate change within WHO policy more widely, both in Europe and globally.

\subsubsection{Intergovernmental Science-Policy Platform on Biodiversity and Ecosystem Services (IPBES)}

The Intergovernmental Science-Policy Platform on Biodiversity and Ecosystem Services (IPBES) is the intergovernmental body that assesses the state of biodiversity and of the ecosystem services it provides to society, in response to requests from decision-makers. As an outcome of its sixth meeting in Medellin/Columbia in March 2018 it decided on a procedure to determine the focal topics of its next assessments. The topic biodiversity and health is currently high on the international political agenda, but it is premature to speculate about a possible IPBES assessment on that topic. It is up to the CBD-COP to put this desire forward formally and the IPBES-Plenary as an independent body can decide to take it on board as a new subject or not (as of August 2018).

Due to this rapid development, with key events taking place towards the end of 2018 (CBD-COP14) and the beginning of 2019 (IPBES-7), we will know only by that time how the topic will have advanced on the agendas of these international treaties and organisations and if it will be considered as a priority for the Post-2020system of the CBD. This would nicely link with the original Millennium Assessment report on health (Corvalan et al. 2005).

In the current IPBES thematic assessments, health is covered in the report on land degradation and restoration (IPBES 2018). It concludes that it is well established that land degradation adversely affects human well-being through the loss of biodiversity and ecosystem services, which has reached critical levels in many parts of the world. In many contexts, land degradation negatively impacts food and water security, as well as human health and safety. Land degradation generally harms psychological well-being by reducing benefits for mental balance, attention, inspiration and healing. Land degradation has particularly negative impacts on the mental health and spiritual well-being of indigenous peoples and local communities. Finally, land degradation, especially in coastal and riparian areas, increases the risk of storm damage, flooding and landslides, with high socio-economic costs and human losses (IPBES 2018). Therefore, there is a clear relationship between land degradation through the loss of biodiversity and ecosystem services on human wellbeing and health, and recognition that land degradation becomes more severe in the face of climate change. 


\subsubsection{Sustainable Development Goals}

The establishment of IPBES coincided with the United Nation's 2030 Agenda on Sustainable Development (UN 2015b). Building on the Brundtland Commission (Brundtland Commission 1987), the Rio Declaration on Environment and Development (UN 1992) and the eight Millennium Development Goals established in 2000 (UN 2000), the SDGs were now developed as a holistic and integrated approach to global development. In 2016, the 2030 Agenda for Sustainable Development comprising 17 SDGs with 169 targets was officially approved during a UN Summit (UN 2015b). The SDGs aim to foster action integrating economic, social and environmental issues (ICSU 2017). In particular, SDG 14 'Life below water' and SDG 15 'Life on land' directly deal with biodiversity, while SDG 13 'Climate change' considers actions for mitigation and adaptation to a changing climate. For health, most prominently the SDG 3 'Good health and well-being', seeks to ensure healthy lives by promoting well-being for all at all ages. Here, a close link with CBD and Ramsar will be beneficial, and the CBD already identified a good alignment of the 2030 Agenda and the Strategic Plan for Biodiversity with many synergies (CBD et al. 2017). Considering the many goals of the 2030 Agenda, it will require good joint sector working to overcome trade-offs and to focus on synergies. Implementation will also crucially depend on translation into policies and practical management at the national and local level to deliver on the targets. Having an overarching goal of 'One Health' (Zinsstag et al. 2015; see also Keune et al. Chap. 15, this volume) may strengthen the sustainable development and conservation agenda.

\subsubsection{ICLEI - Local Governments for Sustainability}

Since concerted efforts by main actors on the local level are pivotal to reach the integration of different policy goals in the fields of biodiversity, climate and public health on the ground, global networks are very important. As the majority of the world's population now lives in cities, and this trend will increase in the future, actions taken by local and regional governments in cities, towns and regions will have a high impact on future developments. ICLEI as a global network of local governments for sustainability with more than 1,500 members and regional offices announced at its World Congress in 2018 the "ICLEI Montréal Commitment and Strategic Vision" (ICLEI - Local Governments for Sustainability 2018), in which five interconnected pathways for change, highlighting the complex relationships among urban systems, are laid out. Climate change, health and biodiversity issues are addressed, with nature being mainstreamed throughout. In addition, one of the pathways to transformative action is through supporting nature-based development. 


\subsection{Conclusions}

Within the last decade much emphasis has been placed on the individual linkages between (1) biodiversity and climate change, (2) biodiversity and health, and (3) health and climate. But so far addressing the three issues together is rare even though they are closely inter-related. Ultimately joint indicators and metrics need to be found to be slotted into sectoral policies.

Integrative research is urgently needed to better understand the triangular relationship between biodiversity in all its forms, levels and inter-relations, climate change effects (temperature and precipitation) and health, taking into account the 'One Health Approach' that goes beyond considering only human health by looking at the entire system.

As evidenced in this volume, there are many opportunities for synergies to tackle public health, biodiversity and climate change adaptation. International and regional conventions as well as international organisations and government programmes are increasingly addressing these issues jointly. They should be encouraged to go further in order to benefit from possible synergies and to avoid detrimental outcomes for society by either no action or by not taking into account aspects beyond a single sector. The World Health Organization already liaises with the global conventions CBD, Ramsar as well as UNFCCC - and this cooperation could be strengthened. Synergies between the conventions on the issue of climate change, its possible impact on health and how well managed biodiversity could help human societies to better cope with the expected changes need to be further explored and developed. Alignment with the 2030 Agenda on Sustainable Development will further foster joint working.

A specific IPBES assessment on biodiversity and health, with associated scenario development under a changing climate, would be very helpful to provide a single up-to-date, policy-relevant document on the issue that could guide further policy development and the international research agenda.

Acknowledgements This work was supported by the German Federal Agency for Nature Conservation (BfN) with funds of the German Federal Ministry for the Environment, Nature Conservation, and Nuclear Safety (BMU) through the research project "Conferences on Climate Change and Biodiversity" (BIOCLIM, project duration from 2014 to 2017, funding code: 351480 020A).

\section{References}

Bellard C, Bertelsmeier C, Leadley P, Thuiller W, Courchamp F (2012) Impacts of climate change on the future of biodiversity. Ecol Lett 15(4):365-377

Brundtland Commission (1987) World commission on environment and development: our common future. Oxford University Press, New York 
Cardinale BJ, Duffy JE, Gonzalez A, Hooper DU, Perrings C, Venail P, Narwani A, Mace GM, Tilman D, Wardle DA, Kinzig AP, Daily GC, Loreau M, Grace JB, Larigauderie A, Srivastava DS, Naeem S (2012) Biodiversity loss and its impact on humanity. Nature 486(7401):59-67

CBD (1992) Convention on biological diversity. United Nations, Montreal. https://www.cbd.int/ convention/text/

CBD (2010) Decision CBD/COP/X/2. Strategic plan for biodiversity 2011-2020. Convention on Biological Diversity. https://www.cbd.int/sp/targets/default.shtml

CBD (2014) COP 12 Decision XII/21. Biodiversity and human health. https://www.cbd.int/decision/cop/default.shtml?id=13384

CBD (2016a) COP 13 Decision XIII/3. Strategic actions to enhance the implementation of the Strategic Plan for Biodiversity 2011-2020 and the achievement of the Aichi Biodiversity Targets, including with respect to mainstreaming and the integration of biodiversity within and across sectors. Cancun. https://www.cbd.int/decisions/cop/?m=cop-13

CBD (2016b) COP 13 Decision XIII/6. Biodiversity and human health. Cancun. https://www.cbd. int/health/cop-13-dec-06-en.pdf

CBD (2017) CBD/SBSTTA/REC/XXI/3. Health and biodiversity. Convention on Biological Diversity. https://www.cbd.int/recommendations/sbstta/?m=sbstta-21

CBD, WHO (2017) Report of the first meeting of the interagency liaison group on biodiversity and health. Geneva. https://www.cbd.int/doc/c/3ff0/ec82/94151f1a58f1d16ad21abe13/hb-lg-201701-01-en.pdf

CBD, FAO, WB, UNEP, UNDP (2017) Biodiversity and the 2030 Agenda for Sustainable Development, Technical Note. Convention on Biological Diversity; Food and Agriculture Organization of the United Nations; The World Bank; UN Environment; United Nations Development Programme. https://www.cbd.int/development/doc/biodiversity-2030-agendatechnical-note-en.pdf

COHAB (2005) COHAB's founding principles. http://www.cohabnet.org/ COHAB2005ConferenceRecommendations.htm

Corvalan C, Hales S, McMichael AJ, Butler C, Campbell-Lendrum D, Confalonieri U, Leitner K, Lewis N, Patz J, Polson K, Scheraga J, Woodward A, Younes M (2005) Ecosystems and human well-being: health synthesis. A Report of the Millennium Ecosystem Assessment. Geneva, Switzerland. https://www.millenniumassessment.org/documents/document.357.aspx.pdf

Díaz S, Pascual U, Stenseke M, Martín-López B, Watson RT, Molnár Z, Hill R, Chan KMA, Baste IA, Brauman KA, Polasky S, Church A, Lonsdale M, Larigauderie A, Leadley PW, van Oudenhoven APE, van der Plaat F, Schröter M, Lavorel S, Aumeeruddy-Thomas Y, Bukvareva E, Davies K, Demissew S, Erpul G, Failler P, Guerra CA, Hewitt CL, Keune H, Lindley S, Shirayama Y (2018) Assessing nature's contributions to people. Science 359(6373):270-272

Füssel H-M, Jol A, Marx A, Hildén M, Aparicio A, Bastrup-Birk A, Bigano A, Castellari S, Erhard M, Georgi B (2017) Climate change, impacts and vulnerability in Europe 2016-An indicator-based report. Copenhagen. https://www.eea.europa.eu/publications/ climate-change-impacts-and-vulnerability-2016

Horwitz P, Finlayson CM (2011) Wetlands as settings for human health: incorporating ecosystem services and health impact assessment into water resource management. Bioscience 61(9):678-688

Horwitz P, Finlayson M, Weinstein P (2012) Healthy wetlands, healthy people: a review of wetlands and human health interactions. Ramsar Technical Report No. 6. http://archive.ramsar.org/ pdf/lib/rtr6-health.pdf

ICLEI - Local Governments for Sustainability (2018) The ICLEI Montréal Commitment and Strategic Vision 2018-2024. Bonn. https://worldcongress2018.iclei.org/wp-content/uploads/ The\%20ICLEI\%20Montr\%C3\%A9al\%20Commitment.pdf?utm_medium=email\&utm_ source=sharpspring\&sslid=MzEzMzY3sDQzNzU1AwA\&sseid=MzQzMDW2MDY0NwIA \&jobid=a3e7a768-0ea3-4cf5-98c7-611b48026f2e

ICSU (2017) Guide to SDG interactions: from science to implementation. Paris. https://council. science/cms/2017/05/SDGs-Guide-to-Interactions.pdf 
IPBES (2018) Thematic assessment report on land degradation and restoration of the Intergovernmental Science-Policy Platform on Biodiversity and Ecosystem Services. Bonn. https://www.ipbes.net/assessment-reports/ldr

IPCC (2014) Climate change 2014: mitigation of climate change. http://www.ipcc.ch/report/ar5/ wg3/

Kabisch N, Frantzeskaki N, Pauleit S, Naumann S, Davis M, Artmann M, Haase D, Knapp S, Korn H, Stadler J, Zaunberger K, Bonn A (2016) Nature-based solutions to climate change mitigation and adaptation in urban areas: perspectives on indicators, knowledge gaps, barriers, and opportunities for action. Ecol Soc 21(2). https://doi.org/10.5751/ES-08373-210239

Kabisch N, Korn H, Stadler J, Bonn A (eds) (2017) Nature-based solutions to climate change adaptation in urban areas - linkages of science, policy and practice. Springer, Cham. https:// doi.org/10.1007/978-3-319-56091-5

Lin BB (2011) Resilience in agriculture through crop diversification: adaptive management for environmental change. Bioscience 61(3):183-193

Lo V (2016) Synthesis report on experiences with ecosystem-based approaches to climate change adaptation and disaster risk reduction. CBD Technical Series No 85. Montreal. https://www. cbd.int/doc/publications/cbd-ts-85-en.pdf

MA (2005) Millenium ecosystem assessment. Island Press, Washington, DC. https://www.millenniumassessment.org/en/index.html

Marselle M, Stadler J, Korn H, Bonn A (eds) (2018) Proceedings of the European Conference "Biodiversity and Health in the Face of Climate Change - Challenges, Opportunities and Evidence Gaps". BfN-Skripten 509. Federal Agency for Nature Conservation, Germany, Bonn. https://doi.org/10.19217/skr509

Parmesan C (2006) Ecological and evolutionary responses to recent climate change. Annu Rev Ecol, Evolu Syst 37:637-669

Pecl GT, Araújo MB, Bell JD, Blanchard J, Bonebrake TC, Chen I-C, Clark TD, Colwell RK, Danielsen F, Evengård B, Falconi L, Ferrier S, Frusher S, Garcia RA, Griffis RB, Hobday AJ, Janion-Scheepers C, Jarzyna MA, Jennings S, Lenoir J, Linnetved HI, Martin VY, McCormack PC, McDonald J, Mitchell NJ, Mustonen T, Pandolfi JM, Pettorelli N, Popova E, Robinson SA, Scheffers BR, Shaw JD, Sorte CJB, Strugnell JM, Sunday JM, Tuanmu M-N, Vergés A, Villanueva C, Wernberg T, Wapstra E, Williams SE (2017) Biodiversity redistribution under climate change: impacts on ecosystems and human well-being. Science 355: eaai9214

Ramsar (2008) Ramsar COP10 DOC. 28 Healthy wetlands, healthy people - a review of wetlands and human health interactions. Draft Executive Summary and Key Messages Chnagwong. http://ramsar.rgis.ch/pdf/cop10/cop10_doc28_e.pdf

Ramsar (2012) Resolution XI.12. Wetlands and health: taking an ecosystem approach. Bucharest. https://www.ramsar.org/document/ resolution-xi12-wetlands-and-health-taking-an-ecosystem-approach

Ramsar (2015) Resolution XII.13 Wetlands and disaster risk reduction. Punta del Este. https:// www.ramsar.org/sites/default/files/documents/library/cop12_res13_drr_e_0.pdf

Romanelli C, Cooper D, Campbell-Lendrum D, Maiero M, Karesh W, Hunter D, Golden C (2015) Connecting global priorities: biodiversity and human health: a state of knowledge review. Geneva. https://www.cbd.int/health/stateofknowledge

Schröter M, Albert C, Marques A, Tobon W, Lavorel S, Maes J, Brown C, Klotz S, Bonn A (2016) National ecosystem assessments in Europe: a review. Bioscience 66(10):813-828

TEEB (2010) The economics of ecosystems and biodiversity: mainstreaming the economics of nature: a synthesis of the approach, conclusions and recommendations of TEEB. http://www. teebweb.org/

Temmerman S, Meire P, Bouma TJ, Herman PM, Ysebaert T, De Vriend HJ (2013) Ecosystembased coastal defence in the face of global change. Nature 504(7478):79

Thomas CD, Cameron A, Green RE, Bakkenes M, Beaumont LJ, Collingham YC, Erasmus BFN, De Siqueira MF, Grainger A, Hannah L, Hughes L, Huntley B, Van Jaarsveld AS, Midgley GF, 
Miles L, Ortega-Huerta MA, Peterson aT, Phillips OL, Williams SE (2004) Extinction risk from climate change. Nature 427(6970):145-148

UN (1992) Rio declaration on environment and development. United Nations, Rio de Janeiro. http://www.un.org/documents/ga/conf151/aconf15126-1annex1.htm

UN (2000) United Nations Millennium Declaration. United Nations, Department of Public Information, New York. http://www.un.org/millennium/declaration/ares552e.htm

UN (2015a) Adoption of the Paris Agreement. Paris. https://unfccc.int/sites/default/files/resource/ docs/2015/cop21/eng/109r01.pdf.

UN (2015b) Transforming our world: the 2030 agenda for sustainable development. A/RES/70/1. https://sustainabledevelopment.un.org/post2015/transformingourworld

Watts N, Adger WN, Agnolucci P, Blackstock J, Byass P, Cai W, Chaytor S, Colbourn T, Collins M, Cooper A, Cox PM, Depledge J, Drummond P, Ekins P, Galaz V, Grace D, Graham H, Grubb M, Haines A, Hamilton I, Hunter A, Jiang X, Li M, Kelman I, Liang L, Lott M, Lowe R, Luo Y, Mace G, Maslin M, Nilsson M, Oreszczyn T, Pye S, Quinn T, Svensdotter M, Venevsky S, Warner K, Xu B, Yang J, Yin Y, Yu C, Zhang Q, Gong P, Montgomery H, Costello A (2015) Health and climate change: policy responses to protect public health. The Lancet 386(10006): 1861-1914

WHO (2015) WHO Workplan on climate change and health. Aims and objectives 2014-2019. Secretariat of the World Health Organisation, Geneva. http://www.who.int/globalchange/ health_policy/climate-change-and-health-workplan-2014-2019.pdf?ua=1

WHO (2016) Fact sheet: climate change and health. Secretariat of the World Health Organisation, Geneva. http://www.who.int/en/news-room/fact-sheets/detail/climate-change-and-health

WHO (2017) Health 2020. A European policy framework and strategy for the 21st century. Copenhagen. http://www.euro.who.int/_data/assets/pdf_file/0011/199532/Health2020-Long. pdf?ua=1

WHO, CBD (2015) Memorandum of Understanding WHO and CBD. Secretariat of the World Health Organisation, Geneva. Secretariat of the Convention of Biological diversity, Montreal. https://www.cbd.int/doc/agreements/agmt-who-2015-07-23-mou-en.pdf

WHO Regional Office for Europe (2016) Urban green spaces and health: a review of evidence. Copenhagen. http://www.euro.who.int/_data/assets/pdf_file/0005/321971/Urban-greenspaces-and-health-review-evidence.pdf?ua $=1$

WHO Regional Office for Europe (2017) Urban green space interventions and health: a review of impacts and effectiveness. Copenhagen. http://www.euro.who.int/_data/assets/pdf_ file/0010/337690/FULL-REPORT-for-LLP.pdf?ua=1

Wolf T, Lyne K, Martinez GS, Kendrovski V (2015) The health effects of climate change in the WHO European Region. Climate 3(4):901-936

Zinsstag J, Schelling E, Waltner-Toews D, Whittaker M, Tanner M (2015) One Health: the theory and practice of integrated health approaches. CABI, Wallingford/Boston

Open Access This chapter is licensed under the terms of the Creative Commons Attribution 4.0 International License (http://creativecommons.org/licenses/by/4.0/), which permits use, sharing, adaptation, distribution and reproduction in any medium or format, as long as you give appropriate credit to the original author(s) and the source, provide a link to the Creative Commons license and indicate if changes were made.

The images or other third party material in this chapter are included in the chapter's Creative Commons license, unless indicated otherwise in a credit line to the material. If material is not included in the chapter's Creative Commons license and your intended use is not permitted by statutory regulation or exceeds the permitted use, you will need to obtain permission directly from the copyright holder.

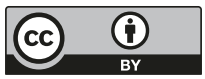

